\title{
FAKTOR YANG MEMPENGARUHI PERILAKU BERALIH KONSUMEN DALAM MENGGUNAKAN KARTU SELULER
}

\author{
Moh. Joko Santoso \\ PT. Astra Agro Lestari, Tbk \\ E-mail:m.joko.santoso@yahoo.co.id
}

\begin{abstract}
This research aims to determine the factors affecting consumer switching behaviour on cellular card in Malang City. Consumer switching behaviour factors included customer service, knowledgeable employees, waiting time to get the customer service, error billing, network coverage, frequent network problem, new scheme, plan for different age,value added service, call rates, hidden charges, short message service charges, internet charges, recharge facilities, offered by competitor family and friend, fancy number, and recharge cost. Consumer switching behaviour in cellular card seen during the last six months. Respondents were card users who have used cellular card at least 6 months. The sum of respondent are 100 users who are selected by purposive sampling. Data were collected by using questionnaires. The data analysed by using logistic regression enter method and backward stepwise. Based on the results of logistic regression analysis exemplified that the constant significance value was less than 0.05 . This meant that the factors of consumer switching behaviour had a significant effect in cellular card. The factors affect consumer switching behaviour had influenced at $37.6 \%$, and $62.4 \%$ influenced by other factors outside this study. Finnaly, the fancy number was the most dominant factors which could influence consumer switching behaviour.
\end{abstract}

Keywords: cellular card user, consumer behavior, switching behavior

\section{PENDAHULUAN}

Perkembangan teknologi komunikasi di Indonesia dalam beberapa tahun terakhir terus mengalami peningkatan yang signifikan. Hal ini dibuktikan dengan penggunaan handphone yang meningkat tajam mulai tahun 2006-2010. Menurut laporan dari Kementrian Komunikasi dan Informatika (2010) data pengguna telepon seluler di Indonesia pada tahun 2006 hanya sekitar 63.803 .015 pelanggan, sedangkan pada kuartal pertama tahun 2010 mencapai 178.432.531 pelanggan. Jumlah yang cukup signifikan ini merupakan sebuah fenomena yang mengisyaratkan adanya beberapa perubahan paradigma mengenai perilaku masyarakat dalam melakukan komunikasi dimana saja, kapan saja, dan siapa saja.

Menurut survei Nielsen Company Indonesia dalam technojournal.com tahun 2011, pengguna telepon seluler terbesar yang pertama di dominasi oleh golongan usia 15 sampai 19 tahun, kedua golongan usia 20 sampai 29 tahun, ketiga golongan usia 30 sampai 39 tahun, keempat golongan 40 sampai 49 tahun, kelima golongan 10 sampai 14 tahun, dan yang terakhir adalah usia 50 tahun keatas. Berdasarkan laporan dari Kementrian Komunikasi dan Informatika (2010), tidak semua operator seluler setiap tahun mengalami peningkatan jumlah pelanggan. Pada tahun 2008 semua operator mengalami peningkatan kecuali Mobile 8 yang justru mengalami penurunan pelanggan sebesar 310.887. Penurunan jumlah pelanggan juga dialami beberapa operator seluler pada tahun 2009, Indosat yang mengalami penurunan pelanggan sebesar 3.373.725, dan STI sebesar 147.475 pelanggan.

Pengguna telepon seluler di Indonesia saat ini seperti yang telah dijelaskan oleh Nielsen Com- 
pany Indonesia didominasi oleh golongan usia muda. Pergeseran usia pengguna telepon seluler ini harus ditangkap oleh provider seluler di Indonesia seperti Telkomsel, Indosat, XL, Hutchison, dan Natrindo dengan produknya masing masing seperti simpati, as, kartu hallo, Im3, mentari, XL, axis, 3 untuk terus bersaing menetapkan tarif termurah dan promo-promo menarik untuk konsumennya. Ketersediaan pilihan kartu seluler dan variasi tarif yang diberlakukan masing-masing kartu seluler menyebabkan semakin banyak pilihan bagi konsumen untuk melakukan switching behaviour ke kartu seluler lain.

Sathis (2011) menjelaskan bahwa peningkatan pengguna telepon seluler maupun kartu seluler salah satu faktornya disebabkan semakin murahnya harga handphone dan juga harga kartu seluler. Hal ini menyebabkan provider menargetkan penduduk berpenghasilan rendah dan juga memperluas segmen usia bagi pengguna telepon seluler sehingga meningkatkan pangsa pasar. Pengurangan jumlah pelanggan yang dialami oleh mobile 8 , indosat, dan STI mengindikasikan bahwa ada perilaku beralih konsumen (consumer switching behaviour) ke kartu seluler lain. Hal ini dikarenakan operator seluleryang lainmengalami peningkatan pelanggan yang signifikan. Pernyataan tersebut juga diperkuat dengan adanya peningkatan jumlah pengguna kartu seluler secara keseluruhan di Indonesia. Fenomena ini menjadi lebih menarik untuk dicermati agar bisa diketahui apa penyebab konsumen melakukan switching ke kartu seluler lain.

Switching behaviour dapat dikatakan sebagai proses menjadi setia pada satu layanan dan beralih ke layanan lain, karena ketidakpuasan atau masalah lain, atau bahkan jika konsumen telah loyal kepada merek tertentu, jika merek tersebut tidak memenuhi kebutuhannya, konsumen akan beralih ke merek pesaing. Banyak faktor yang berbeda dan determinan yang mempengaruhi konsumen dalam beralih layanan dari satu layanan ke yang lain. Biaya yang dikeluarkan selama proses peralihan disebut biaya peralihan. Loyalitas konsumen didefinisikan sebagai derajat dimana konsumen mengulangi perilaku pembelian dari penyedia layanan, konsumen memiliki sikap positif terhadap pro- vider, dan menganggap hanya menggunakan operator ini ketika kebutuhan untuk layanan ini muncul.

Kehilangan konsumen adalah kemunduran serius bagi perusahaan dalam hal pendapatan baik sekarang maupun dimasa yang akan datang. Selain kehilangan manfaat yang telah dibahas diatas, perusahaan perlu menginvestasikan sumber daya yang ada dalam menarik konsumen baru untuk menggantikan konsumen yang telah hilang. Peters (1987) dalam Sathis (2011) menunjukkan bahwa membutuhkan biaya lima kali lebih banyak untuk mendapatkan konsumen baru daripada mempertahankan konsumen yang lama. Akibatnya, mempertahankan basis konsumen saat ini jauh lebih menarik dan layak daripada mencari konsumen baru.

Menurut Sathis (2011), consumer switching behavior disebabkan beberapa faktor yaitu kesalahan customer service, pengetahuan karyawan, waktu menunggu untuk mendapatkan pelayanan konsumen, kesalahan penagihan, jangkauan jaringan, frekuensi masalah jaringan, rencana baru, rencana untuk kelompok umur yang berbeda, biaya untuk layanan tambahan, tarif panggilan, tarif yang disembunyikan, tarif SMS, tarif internet, tawaran dari pesaing, pengaruh keluarga dan teman, nomor cantik, dan biaya isi ulang.

Penelitian tentang switching behaviour sudah dilakukan oleh Kaeveney (1995), dari penelitian tersebut menghasilkan model customer switching behaviour pada perusahaan jasa (perusahaan-perusahaan sejenis). Penelitian switching behaviour pada celluler service juga dilakukan oleh Sathis (2011) di Chenai India, dengan temuan adanya korelasi antara switching dalam menggunakan kartu seluler dengan faktor-faktor yang telah dijelaskan seperti pelayanan konsumen, masalah pelayanan dan lainnya. Dalam penelitian Sathis (2011) tersebut, peneliti sekarang bermaksud melakukan penelitian tentang switching behaviour di Kota Malang Indonesia. Penelitian tentang switching behaviour dalam menggunakan kartu seluler belum pernah dilakukan di Kota Malang, sehingga hal ini menjadi masalah yang menarik untuk diteliti dan dianalisa lebih lanjut. 
Berdasarkan latar belakang penelitian tersebut diatas, maka perumusan masalah dalam penelitian ini adalah yang pertama apakah faktorfaktor kesalahan customer service, pengetahuan karyawan, waktu menunggu untuk mendapatkan pelayanan konsumen, kesalahan penagihan, jangkauan jaringan, frekuensi masalah jaringan, rencana baru, rencana untuk kelompok umur yang berbeda, biaya untuk layanan tambahan, tarif panggilan, tarif yang disembunyikan, tarif SMS, tarif internet, fasilitas isi ulang, tawaran dari pesaing, pengaruh keluarga dan teman, nomor cantik, dan biaya isi ulang berpengaruh signifikan terhadap perilaku beralih konsumen (consumer switching behaviour) dalam menggunakan kartu seluler?, kemudian dari faktor - faktor yang dikembangkan oleh Sathis (2011) tersebut, apakah yang dominan mempengaruhi perilaku beralih konsumen (consumer switching behaviour) dalam menggunakan kartu seluler?.

Agar hasil penelitian ini nantinya tidak menyimpang dari rumusan masalah maka masalah dibatasi pada faktor-faktor perilaku beralih konsumen (consumer switching behaviour) yang telah dijelaskan dalam Sathis (2011). Untuk mengetahui pengaruh faktor - faktor kesalahan customer service, pengetahuan karyawan waktu menunggu untuk mendapatkan pelayanan konsumen, kesalahan penagihan, jangkauan jaringan, frekuensi masalah jaringan, rencana baru, rencana untuk kelompok umur yang berbeda, biaya untuk layanan tambahan, tarif panggilan, tarif yang disembunyikan, tarifSMS, tarif internet, fasilitas isi ulang, tawaran dari pesaing, pengaruh keluarga dan teman, nomor cantik, dan biaya isi ulang terhadap perilaku beralih konsumen (consumer switching behaviour) dalam menggunakan kartu seluler, sedangkan untuk mengetahui faktor - faktor yang dominan mempengaruhi perilaku beralih konsumen (consumer switching behaviour) dalam menggunakan kartu seluler?

\section{TINJAUAN PUSTAKA}

Dalam menunjang penelitian ini, maka diperlukan suatu dasar yang dapat digunakan sebagai bahan pertimbangan atau acuan. Penelitian tedahulu dilakukan oleh Keaveney (1995) melakukan penelitian tentang customer switching behaviour dalam industri jasa. Penelitian dengan sampel sebanyak 468 responden dan dilakukan pada empat puluh lima (45) jenis industri jasa yang berbeda. Menghasilkan temuan yang menjelaskan model dasar dari customer switching behaviour pada industri pelayanan yang dapat membantu untuk mengerti bagaimana pelanggan meninggalkan dan mencari penyediajasa lainnya.

Dari pengembangan teori dan risetnya Keaveney (1995) diperoleh bahwa service switching behaviour dominan dipengaruhi oleh faktorfaktor dan sub kategori penyebab pelanggan beralih yaitu: pricing (penetapan harga), inconvenience (menyusahkan / ketidaknyamanan) core service failure (kegagalan dalam memberikan pelayanan utama), service encounter failures (kegagalan berinteraksi dalam pelayanan), response to service failure (tanggapan terhadap kelalaian pelayanan), competition (kompetisi), ethical problem (masalah etika) dan involuntari switching (terpaksa pindah). Akibat dari keinginan pindah (service switching) adalah word of mouth (membicarakan dari mulut kemulut) dan search new service (mencari jenis pelayanan baru) Penelitian Sathish (2011) dilakukan dengan cara survei terhadap pengguna kartu seluler di Chenai India. Tujuan penelitian tersebut, pertama untuk mengidentifikasi faktor yang mempengaruhi konsumen dalam melakukan switching provider. Kedua untuk menemukan provider yang paling disukai di Chennai. Ketiga untuk menemukan faktor utama yang mempengaruhi konsumen mengambil keputusan pembelian kartu seluler.

Teori mengenai Brand Switching, Menurut Lin (2000) loyalitas merek adalah kesetiaan terhadap merek tertentu dimana mewakili karakteristik yang diinginkan konsumen yang hanya akan membeli produk merek tersebut dari pada melakukan perpindahan merek. Pembelian ulang ke perpindahan merek diklarifikasikan menjadi beberapa kelompok yaitu pertama potential swicher, yaitu kelompok ini terdiri dari seluruh pelanggan yang loyal terhadap suatu produk namun ada 
potensi untuk dipengaruhi oleh berbagai macam faktor untuk beralih merek. Kedua repeat buyer, yaitu kelompok pembeli yang membuat pilihan produk untuk sama untuk pada waktu yang lalu, waktu sekarang dan waktu untuk masa depan, dan ketiga brand switcher, kelompok ini terdiri dari sebagian pembeli yang akan berpindah merek setidaknya satu kali ketika merek membuat pilihan merek untuk pembelian sekarang atau dimasa yang akan datang. Konsep yang mendasari penelitian ini adalah tentang tingkat loyalitas merek yang lebih khusus yaitu berkaitan dengan perilaku konsumen yang berpindah-pindah (consumer switching behaviour) atau konsumen yang suka berpindah merek (brand switcing). Menurut Dharmmesta (1999) Brand switching adalah Perilaku perpindahan merek yang dilakukan konsumen karena beberapa alasan tertentu, atau diartikan juga sebagai kerentanan konsumen untuk berpindahkemerek lain.

Penilaian konsumen terhadap merek dapat timbul dari berbagai variabel, seperti pengalaman konsumen dengan produk sebelumnya dan pengetahuan konsumen tentang produk. Pengalaman konsumen dalam memakai produk dapat memunculkan komitmen terhadap merek produk tersebut. Menurut Kahle dalam Dharmesta (1999) komitmen merek dapat didefinisikan sebagai kesertaan emosional atau perasaan. Ketidakpuasan emosional konsumen dari pengalaman tentang produk dapat menyebabkan konsumen merasa tertarik untuk mencari merek lain diluar merek yang biasanya. Pencarian merek lain ini dapat dilakukan dengan mendapatkan informasi melalui media cetak. Media audio ataupun melalui interpersonal, dimana tujuan akhirnya adalah perilaku untuk berpindah merek (brand switching).

Menurut Simamora (2004) dapat dijelaskan bahwa konsumen yang sering kali melakukan perpindahan merek (Brand switching) dalam pembeliannya termasuk dalam tipe perilaku pembelian yang mencari keragaman (Variety Seeking Buying Behaviour) Peralihan merek juga ditandai dengan keterlibatan yang rendah. Konsumen tidak melalui tahap-tahap keyakinan, sikap atau perilaku yang normal. Konsumen tidak secara ekstensif mencari informasi mengenai merek, tetapi memilih suatu merek karena merek tersebut terasa akrab (brand familiarity).

Switching Behaviour yang menurut Sathis (2011) adalah perilaku konsumen di mana perilaku dari konsumen berbeda berdasarkan tingkat kepuasan konsumen dengan penyedia atau perusahaan. Switching behaviour dapat dikatakan sebagai proses menjadi setia pada satu layanan dan beralih ke layanan lain, karena ketidakpuasan atau masalah lain. Bahkan jika konsumen loyal kepada merek tertentu, jika merek tidak memenuhi kebutuhannya, konsumen beralih ke merek pesaing. Ada banyak faktor yang berbeda dan determinan yang mempengaruhi konsumen dalam beralih layanan mereka dari satu layanan ke yang lain. Sedangkan dalam konteks jasa, switching mengacu pada mengganti penyedia jasa yang sekarang digunakan dengan jasa yang lain. Keaveney dan Parthasarathy (2001), mendefinisikan switching dengan lebih jelas yaitu "ketika pelanggan terus menggunakan kategori layanan (misalnya, layanan online) tetapi beralih dari satu penyedia layanan (misalnya, Prodigy) yang lain (misalnya AOL) II.

Hambatan untuk Melakukan Switching (Barrier to Switching), yaitu kemampuan dan kemauan konsumen untuk beralih sangat penting. Barrow (2007) dalam Xavier (2008) menyatakan, jika pergantian tidak disarankan atau dihalangi, karena ini bisa berdampak tidak hanya pada sisi permintaan tetapi juga berpotensi menambah hambatan pada sisi penawaran. Hal demikian dapat mengurangi efektivitas persaingan dan berfungsi untuk membatasi manfaat dinyatakan konsumen akan berasal darinya. Hambatan perpindahan dapat hadir karena biaya switching yang tinggi. Biaya switching dapat didefinisikan sebagai biaya nyata atau yang dirasakan terjadi ketika mengubah provider tetapi yang tidak terjadi dengan provider yang digunakan saatini.

Sherif dan Hovland (1961) dalam Lee (2005) menyatakan bahwa berdasarkan teori asimilasi kontras, konsumen memiliki zona ketidakpedulian dan mentolerir kinerja kurang lancar yang diharapkan dalam kinerja aktual untuk memenuhi batas minimum. Dengan demikian, perubahan faktor penentu dapat menyebabkan switching setelah 
mereka melanggar zona ini. Selanjutnya, faktorfaktor penentu baru dapat memicu transisi loyalitasswitching. Keaveney (1995) dalam Lee (2005) Studi menunjukkan bahwa faktor-faktor yang memprediksi hubungan positif mungkin berbeda dari yang memprediksi hubungan negatif. Misalnya, Lewis (1991) dalam Lee (2005) menemukan bahwa kenyamanan dan layanan yang ditawarkan adalah alasan utama yang mempengaruhi pilihan Bank di kalangan kaum muda Inggris. Namun setelah menggunakan layanan perbankan, ketidakpuasan dengan layanan pelanggan merupakan faktor utama untuk switching. Demikian pula, Mazursky et al, (1987) dalam Lee (2005) menunjukkan bahwa switching dapat terjadi bahkan ketika faktorfaktor penentu loyalitas terpuaskan.

Konsep Customer Switching behaviour, menurut Palmer et al, 1998 dalam Zikiene (2011) Customer Switching behaviour merupakan proses dinamis yang berkembang selama periode waktu tertentu dan mengakibatkan hubungan berakhir. Literatur ilmiah menunjukkan bahwa ketika Customer Switching behaviour dihubungkan dengan ketidaksetiaan pelanggan perlu dibuat dimensi perbedaan antara perilaku dan sikap. Customer Switching behaviour bisa langsung diekspresikan melalui perilaku tetapi tidak pada sikap tidak setia.

Menurut Parasurahman at al, dalam Zikiene (2011) dalam Analisis dari literatur ilmiah menunjukan bahwa perbedaan faktor yang mempengaruhi customer switching behaviour ada, dan mereka sering bergantung pada industri, sektor individu dan bisnis yang spesifik. Tergantung pada pengaruh, faktor yang mempengaruhi customer switching behaviour dibagi menjadi pendukung (faktor yang menekan loyalitas) dan menekan switching behaviour (faktor pendukung loyalitas) seperti yang dijelaskan pada Gambar 1 berikut:

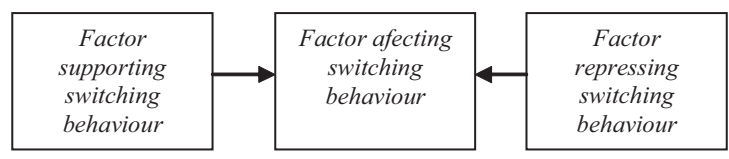

Gambar 1. Faktor yang Mempengaruhi Switching Behaviour
Faktor yang mendukung customer switching behaviour mewakili satu dari dua kelompok dari faktor yang mempunyai pengaruh pada perilaku switching tersebut. Faktor ini adalah faktor yang memiliki dampak buruk dan memungkinkan pelanggan untuk mengakhiri hubungan dengan organisasi mereka, dan mengurangi sikap dan perilaku loyalitas pelanggan. Faktor yang meneken customer switching behaviour dapat diperlakukan sebagai kendala yang sengaja diciptakan oleh organisasi atau terbentuk secara alami, ketika membangun kondisi bagi pelanggan untuk berlangganan selama mungkin dan mencegah mereka mencari segala alternatif lain yang tersedia.

Sedangkan faktor - faktor yang mempengaruhi perilaku beralih konsumen (consumer switching behaviour) Menurut Keaveney (1995) Model dari Customer Switching Behavior pada industri jasa atau faktor-faktor yang mempengaruhi pelanggan dalam melakukan switching pada industri jasa adalah a) Pricing (penetapan harga), b) Inconvenience (menyusahkan / ketidaknyamanan), c) Core service failure (kegagalan dalam memberikan pelayanan utama), d)Service encounter failures (kegagalan berinteraksi dalam pelayanan), e) Response to service failure (tanggapan terhadap kelalaian pelayanan), f) Competition (kompetisi), g) Ethical problem (masalah etika), h) Involuntari switching (terpaksa pindah).

Menurut beberapa penulis seperti Nordman (2004), Keaveney (1995), Colgate (2001) dan beberapa penulis lainnya dalam Zikiene (2011) ada penambahan faktor-faktor yang yang mengikuti perilaku beralih konsumen (consumer switching behaviour) adalah Dissatisfactory quality. Kualitas dari produk atau jasa menjadi tidak bisa diterima oleh konsumen, kemudian Variety seeking hal ini menjadi alami bagi seseorang untuk mencari variasi. Selanjutnya Change of service personal. Perubahan tenaga pelayanan pribadi dapat mempengaruhi customer switching behaviour khususnya jika tenaga pelayanan (tergantung pada sifat produk / jasa) hubungan erat kepada pelanggan atau sedang membangun hubungan yang dekat dengan mereka, ada juga yang dikenal dengan Refusal to modify 
service/product (if it technologically possible) or to provide an axceptional service. Penolakan modifikasi dari produk / jasa atau khususnya peningkatan pelayanan atau kegagalan untuk menyampaikan penambahan nilai dapat memotivasi pelanggan melihat solusi alternatif untuk masalah ini, kemudian Change of the place of residence of the customer. Perubahan tempat tinggal dapat mempengaruhi consumer switching behaviour jika jasa atau produk dari provider tertentu tidak terdapat didekat tempat tinggal konsumen, ada juga New value, yaitu tampilan total dari produk baru atau jasa di pasarmampu menawarkan sebuah nilai tambah bagi konsumen dapat juga membesakan hati mereka untuk pindah kepada provider produk/ jasa lain.

\section{METODE PENELITIAN}

Berdasarkan riset Nielsen Company Indonesia tersebut peneliti memilih melakukan penelitian di Kota Malang. Jenis penelitian yang dilakukan bersifat deskriptif. Metode pengumpulan data yang digunakan adalah metode survey. Variabel independent atau variabel bebas dalam penelitian ini adalah perilaku beralih konsumen (consumer switching behaviour) dengan indikator satu kesalahan customer service, dua yaitu pengetahuan terhadap produk dan pengetahuan terhadap layanan, tiga waktu menunggu untuk mendapatkan pelayanan konsumen, empat kesalahan penagihan, lima Jangkauan jaringan, dan keenam yaitu frekuensi masalah jaringan, tujuh adalah rencana baru, delapan adalah rencana untuk kelompok umur yang berbeda, sembilan, yaitu biaya untuk layanan tambahan, sepuluh adalah Tarif panggilan, dan sebelas adalah tarif yang disembunyikan, duabelas adalah tariff SMS. Penelitian lapangan yaitu dengan cara memberikan daftar pertanyaan (kuisioner) kepada responden untuk dijawab.

Alasan menggunakan metode analisis data regresi logistik yaitu dapat digunakan untuk memprediksi hubungan atau pengaruh, dalam hal ini adalah digunakan untuk mengetahui switcher atau stayer seorang konsumen pengguna kartu seluler.

\section{HASIL PENELITIAN DAN PEMBAHASAN}

Berdasarkan hasil uji hipotesis yang dilakukan dan dengan melihat hasil regresi logistik metode backward stepwise, dari 18 faktor yang mempengaruhi perilaku beralih konsumen hanya ada 6 faktor yang berpengaruh signifikan terhadap perilaku beralih konsumen dalam menggunakan kartu seluler. Faktor itu antara lain kesalahan customer service, rencana untuk kelompok umur yang berbeda, tarif panggilan, tarif SMS, tarif internet, dan nomor cantik.

Faktor lain yaitu pengetahuan karyawan, waktu menunggu untuk mendapatkan pelayanan konsumen, kesalahan penagihan, jangkauan jaringan, frekuensi masalah jaringan, rencana baru, rencana untuk kelompok umur yang berbeda, biaya untuk layanan tambahan, tarif yang disembunyikan, fasilitas isi ulang, tawaran dari pesaing, pengaruh keluarga dan teman, dan biaya isi ulang mempunyai nilai alpha lebih dari 0,05 yang berarti tidak berpengaruh signifikan. Hal ini dikarenakan sebaran kuesioner yang berdasarkan cakupan usia terlalu luas sehingga rata-rata responden kurang memahami inti dari kuesioner.

Produk yang diteliti dalam penelitian ini adalah semua operator seluler yang mempunyai kelebihan dan kekurangan berbeda-beda sehingga jawaban responden tidak bisa seragam dan menjadi kurang akurat. Faktor-faktor yang mempengaruhi perilaku beralih konsumen dirujuk dari jurnal internasional oleh Sathis (2011) yang melakukan penelitian di Chenai India, sehingga memungkinkan karena karakteristik responden yang berbeda menjadikan hasil penelitian ini berbeda jauh dari penelitian sebelumnya. Dalam uji regresi logistik masih diperlukan uji asusmi klasik, tetapi yang diuji hanya variabel bebasnya saja (faktor-faktor perilaku beralih konsumen) hal ini untuk memastikan tidak ada hubungan antara variabel faktor-faktor perilaku beralih konsumen yang satu dengan variabel yang lainnya. Uji asumsi klasik dilakukan dengan cara uji multikolinearitas, caranya yaitu dengan membandingkan perhitungan akar dari nilai R. Apabila hasil akar kuadrat dari nilai R lebih besar dari 0,85 
maka terjadi multikolinearitas. Pada tabel 4.50 diketahui nilai $\mathrm{R}$ sebesar 0,376dengan demikian nilai akar kuadrat $\mathrm{R}$ adalah0,613, berarti 0,613< 0,85 artinya tidak ada multikolinearitas atau hubungan variabelfaktor faktor perilaku beralih konsumen yang satu dengan variabel faktor faktor perilaku beralih konsumen yang lain, bisa dikatakan variabel faktor faktor perilaku beralih konsumen bebas dari multikolinearitas.

Pengujian regresi logistik dari faktor-faktor yang mempengaruhi perilaku beralih konsumen dalam menggunakan kartu seluler dilakukan dengan bantuan SPSS for Windows 15.0. Untuk mengetahui pengelompokan jumlah responden pengguna kartu seluler yang beralih (switch) dan tidak beralih (stayer) dapat dilihat pada Tabel 1 dibawah ini.

Tabel 1. Pengelompokan Pengguna Kartu Seluler

\begin{tabular}{ccccc}
\hline \multirow{2}{*}{ Observasi } & \multicolumn{2}{c}{ Prediksi } & \multirow{2}{*}{ Total } & \multirow{2}{*}{$\%$} \\
\cline { 2 - 3 } & Stayer & Switcher & & \\
\hline 0 & 13 & 16 & 29 & 44,8 \\
1 & 7 & 64 & 71 & 90,1 \\
& & & & 77,0 \\
\hline
\end{tabular}

Tabel 1 tersebut menunjukan bahwa dari 100 responden pengguna kartu seluler di di Kota Malang terdapat 71 pengguna kartu seluler yang beralih (switcher) dan setelah dianalisis menggunakan analisis regresi logistik terdapat 7 pengguna kartu seluler yang tidak beralih menggunakan kartu seluler (stayer), atau dapat diartikan 90,1\% dari 71 pengguna kartu seluler dapat dikelompokan dengan tepat oleh model. Pada kategori tidak beralih menggunakan kartu seluler (stayer) terdapat 29 responden yang termasuk dalam kategori tidak beralih (stayer), setelah dianalisis terdapat 16 pengguna kartu seluler yang beralih (switcher), atau $44,8 \%$ dari 29 responden yang tidak beralih menggunakan kartu seluler (stayer) dapat dikelompokan secara tepat oleh model. Berdasarkan hasil analisis diatas dapat diprediksi pengguna kartu seluler yang beralih (switch) akan mencapai tingkat kebenaran sebesar $77 \%$.

Variabel faktor-faktor yang mempengaruhi perilaku beralih konsumen dalam menggunakan kartu seluler dikatakan memiliki pengaruh yang signifikan apabila nilai signifikansinya $<0,05$. Hubung- an antara faktor-faktor yang mempengaruhi perilaku beralih konsumen dalam menggunakan kartu seluler dapat dilihat pada tabel berikut:

Tabel 2. Hubungan Faktor-faktor yang Mempengaruhi Perilaku Beralih Konsumen

\begin{tabular}{lll}
\hline Chi-square & Sig & R \\
\hline 30.570 & 0.032 & 0.376 \\
\hline
\end{tabular}

Pada Tabel 2 tersebut dapat diketahui bahwa nilai signifikansinya adalah $0,032<0,05$ berarti ada hubungan antara faktor-faktor perilaku beralih konsumen dengan perilaku beralih konsumen dalam menggunakan kartu seluler. Nilai sig yang kurang dari 0,05 juga berarti bahwa variabel-variabel yang ada berpengaruh nyata terhadap perilaku beralih (switching).

Selain itu dapat dilihat bahwa nilai R sebesar 0,376, artinya kontribusi variabel faktor-faktor perilaku beralih konsumen berpengaruh sekitar $37,6 \%$, dan sisanya sekitar $62,4 \%$ dipengaruhi oleh variabel lain yang tidak dimasukan kedalam persamaan. Untuk mengetahui pengaruh faktor-faktor perilaku beralih konsumen dalam menggunakan kartu seluler dapat dilakukan dengan cara melihat tingkat signifikansinya. Jika nilai signifikansi $<0,05$ maka hipotesis yang diajukan diterima.Hasil analisis regresi logistik dapat dilihat pada tabel 3 berikut.

Menggunakan metode enter diketahui bahwa variabel yang memiliki nilai signifikansi kurang dari 0,05 adalah variabel kesalahan customer service, rencana untuk kelompok umur yang berbeda, tarif SMS, dan nomor cantik, maka yang memiliki pengaruh signifikan terhadap perilaku beralih konsumen (consumer switching behaviour) adalah variabel kesalahan customer service, rencana untuk kelompok umur yang berbeda, tarif SMS, dan nomor cantik, sedangkan variabel yang lain berpengaruh pada tingkat signifikasi yang berbeda. Untuk mengetahui variabel yang berpengaruh secara signifikan dilakukan pengujian ulang dengan metode backward stepwise(wald), dengan menggunakan metode ini variabel yang tidak signifikan akan langsung dihilangkan (removed). Hasil pengujian dapat dilihat pada tabel 4 : 
28 Jurnal Manajemen Bisnis • Volume 3 No. 01 • Edisi April 2013

Tabel 3. Hasil Analisis Regresi Logistik Metode Enter

\begin{tabular}{lrrrr}
\hline \multicolumn{1}{c}{ Variabel } & \multicolumn{1}{l}{ B } & \multicolumn{1}{c}{ S.E. } & \multicolumn{1}{c}{ Wald } & \multicolumn{1}{l}{ Sig. } \\
\hline Kesalahan customer service & .806 & .394 & 4.173 & .041 \\
Pengetahuan karyawan & -.292 & .381 & .587 & .443 \\
Waktu menunggu untuk mendapatkan pelayanan & -.453 & .362 & 1.569 & .210 \\
konsumen & .423 & .358 & 1.400 & .237 \\
Kesalahan penagihan & -.447 & .453 & .970 & .325 \\
Jangkauan jaringan & .159 & .429 & .138 & .710 \\
Frekuensi masalah jaringan & -.115 & .355 & .105 & .746 \\
Rencana baru & -.867 & .360 & 5.804 & .016 \\
Rencana untuk kelompok umur yang berbeda & -.135 & .316 & .184 & .668 \\
Biaya untuk layanan tambahan & -.577 & .524 & 1.213 & .271 \\
Tarif panggilan & -.252 & .394 & .408 & .523 \\
Tarif yang disembunyikan & 1.080 & .499 & 4.684 & .030 \\
Tarif SMS & .862 & .461 & 3.499 & .061 \\
Tarif internet & -.480 & .393 & 1.493 & .222 \\
Fasilitas isi ulang & .402 & .327 & 1.512 & .219 \\
Tawaran dari pesaing & .100 & .331 & .091 & .763 \\
Pengaruh keluarga dan teman & -.826 & .330 & 6.246 & .012 \\
Nomor cantik & -.133 & .389 & .117 & .732 \\
Biaya isi ulang & 1.295 & .310 & 17.495 & .000 \\
Constant & & &
\end{tabular}

Tabel 4. Hasil Analisis Regresi Logistik Metode Backward Stepwise

\begin{tabular}{lcccc}
\hline \multicolumn{1}{c}{ Variabel } & B & S.E. & Wald & Sig \\
\hline Kesalahan customer service & .500 & .259 & 3.725 & .054 \\
Rencana untuk kelompok umur & -.623 & .296 & 4.439 & .035 \\
yang berbeda & -1.012 & .465 & 4.741 & .029 \\
Tarif panggilan & .718 & .377 & 3.632 & .057 \\
Tarif SMS & .877 & .386 & 5.151 & .023 \\
Tarif internet & -.861 & .298 & 8.344 & .004 \\
Nomor cantik & 1.161 & .276 & 17.686 & .000 \\
Constant & & & & \\
\hline
\end{tabular}

Berdasarkan tabel 4, variabel yang memiliki nilai signifikansi $<0,05$ adalah kesalahan customer service, rencana untuk kelompok umur yang berbeda, tarif panggilan, tarif SMS, tarif internet dan nomor cantik. Untuk variabel faktor-faktor perilaku beralih konsumen yang paling dominan berpengaruh dalam menggunakan kartu seluler adalah nomor cantik karena nilai signya $(0,004)<$ 0,05.Dari nilai koefisien regresi yang ada pada tabel 4.36maka dapat dibuat persamaan $\mathrm{Z}=1.161+$ 0.500 (kesalahan customer service) -0.623 (Rencana untuk kelompok umur yang berbeda) 1.012 (tarif panggilan) +0.718 (tarif SMS $)+0.877$ (tarif internet) - 0.861 (nomor cantik).
Variabel faktor-faktor perilaku beralih kosumen yang lain yang tidak mempunyai pengaruh yang signifikan tidak perlu dimasukkan dalam persamaan. Dari persamaan $\mathrm{Z}$ tersebut dapat ditentukan besarnya probabilitas perilaku beralih konsumen dalam menggunakan kartu seluler. Untuk pengguna kartu seluler yang pertama diperoleh hasil total skor sebagai berikut:kesalahan customer service $=8$, rencana untuk kelompok umur yang berbeda $=6$, tarif panggilan $=6$, tarif SMS $=12$, tarif internet $=6$ dan nomor cantik $=4$. Setelah diperoleh nilai Z, maka dapat ditentukan besarnya probabilitas perilaku beralih konsumen dalam 
menggunakan kartu seluler dengan menggunakan bantuan software SPSS for Windows versi 15.0.

Data total skor yang dimasukkan dalam persamaan Z dengan menggunakan bantuan software SPSS for Windows versi 15.0 diperoleh nilai probabilitas sebesar 0,022239111, maka probabilitas sukses untuk responden yang pertama sebesar $22,23 \%$, dan probabilitas gagal sebesar $77,77 \%$. Nilai probabilitas yang $<0,5$ termasuk kelompok pengguna kartu seluler yang tidak beralih (stayer), sedangkan nilai probabilitas $>0,5$ termasuk kelompok pengguna kartu seluler yang beralih (switcher).

Hasil pengujian hipotesis diketahui faktorfaktor perilaku beralih (switching behaviour) berpengaruh terhadap perilaku beralih dalam menggunakan kartu seluler yang dilihat dari nilai signifikansi $0,032<0,05$ dan juga uji korelasi parsial. Variabel yang paling dominan dalam memberikan pengaruh adalah variabel nomor cantikdengan nilai sig 0,004 , dan nilai R 0,2863, dengan kata lain hipotesis pertama diterima dan hipotesis kedua ditolak. Berikut adalah pembahasan dari masing - masing variabel faktor-faktor perilaku beralih konsumen dalam menggunakan kartu seluler 1. Kesalahan Customer Service diperoleh nilai signifikansi sebesar 0,054 yang lebih besar dari $\alpha 0,05$. Hal ini berarti bahwa tidak terdapat pengaruh yang signifikan antara variabel kesalahan customer servicedengan perilaku beralih dalam menggunakan kartu seluler. Berarti variabel kesalahan customer servicebukan merupakan faktor yang signifikan mempengaruhi perilaku beralih konsumen dalam menggunakan kartu seluler.Hasil penelitian ini mendukung penelitian sebelumnya yang dilakukan oleh Sathis (2011), tetapi tidak sesuai dengan yang dilakukan oleh Keaveney (1995). 2. Pengetahuan Karyawan, diperoleh nilai signifikansi sebesar 0.443 yang lebih besar dari $\alpha 0,05$. Hal ini berarti bahwa tidak terdapat pengaruh yang signifikan antara variabel pengetahuan karyawandengan perilaku beralih dalam menggunakan kartu seluler. Variabel pengetahuan karyawanbukan merupakan faktor yang signifikan mempengaruhi perilaku beralih dalam menggunakan kartu seluler.
Hasil penelitian sesuai dengan penelitian sebelumnya yang dilakukan oleh Sathis (2011) yang juga menyatakan bahwa pengetahuan karyawan bukan merupakan faktor yang signifikan mempengaruhi konsumen dalam beralih menggunakan kartu seluler lain. Tidak sesuai dengan yang dilakukan oleh Keaveney (1995). Penelitian tersebut menyatakan bahwa hingga $34 \%$ responden beralih menggunakan service lain dikarenakan service encounter failure. 3. Waktu tunggu untuk mendapatkan pelayanan konsumen diperoleh nilai signifikansi sebesar 0.210yang lebih besar dari $\alpha$ 0,05 . Hal ini berarti bahwa tidak terdapat pengaruh yang signifikan antara variabel waktu tunggu untuk mendapatkan pelayanan konsumen dengan perilaku beralih dalam menggunakan kartu seluler. Berarti variabel waktu tunggu untuk mendapatkan pelayanan konsumen bukan merupakan faktor yang mempengaruhi perilaku beralih dalam menggunakan kartu seluler.

Hasil penelitian sesuai dengan penelitian sebelumnya yang dilakukan oleh Sathis (2011)yang juga menyatakan bahwa faktor waktu tunggu untuk mendapatkan pelayanan konsumen bukan merupakan faktor yang signifikan mempengaruhi konsumen dalam beralih menggunakan kartu seluler lain. Tidak sesuai dengan yang dilakukan oleh Keaveney (1995). Penelitian tersebut menyatakan bahwa hingga $21,6 \%$ responden beralih menggunakan service lain dikarenakan inconvinience. 4. Kesalahan Penagihan diperoleh nilai signifikansi sebesar 0,237 yang lebih besar dari á 0,05 . Hal ini berarti bahwa tidak terdapat pengaruh yang signifikan antara variabel kesalahan penagihandengan perilaku beralih dalam menggunakan kartu seluler. Berarti variabel kesalahan penagihanbukan merupakan faktor yang mempengaruhi perilaku beralih dalam menggunakan kartu seluler.

Hasil penelitian sesuai dengan penelitian sebelumnya yang dilakukan oleh Sathis (2011) yang juga menyatakan bahwa faktor kesalahan penagihan bukan merupakan faktor yang signifikan mempengaruhi konsumen dalam beralih menggunakan kartu seluler lain. Tidak sesuai dengan yang dilakukan oleh Keaveney (1995). Penelitian tersebut menyatakan bahwa hingga $44 \%$ responden 
menyebutkan core service failure sebagai faktor yang menyebabkan switching. Dalam penelitian tersebut terdapat $11 \%$ responden yang beralih menggunakan service lain dikarenakan hanya karena core service failure sebagai alasannya. 5 . Jangkauan jaringan, diperoleh nilai signifikansi sebesar 0,325yang lebih besar dari á 0,05. Hal ini berarti bahwa tidak terdapat pengaruh yang signifikan antara variabel jangkauan jaringandengan perilaku beralih dalam menggunakan kartu seluler. Berarti variabel jangkauan jaringanbukan merupakan faktor yang mempengaruhi perilaku beralih dalam menggunakan kartu seluler. Hasil penelitian ini tidak sesuai dengan penelitian sebelumnya yang dilakukan oleh Sathis (2011). Dalam Sathis (2011) menyatakan bahwa jangkauan jaringan merupakan faktor yang signifikan dan dominan mempengaruhi perilaku beralih konsumen dalam menggunakan kartu seluler. 6. Frekuensi masalah jaringan, diperoleh nilai signifikansi sebesar 0,710 yang lebih besar dari $\alpha 0,05$. Hal ini berarti bahwa tidak terdapat pengaruh yang signifikan antara variabel frekuensi masalah jaringandengan perilaku beralih dalam menggunakan kartu seluler. Berarti variabel frekuensi masalah jaringanbukan merupakan faktor yang mempengaruhi perilaku beralih dalam menggunakan kartu seluler.

Hasil penelitian ini tidak sesuai dengan penelitian sebelumnya yang dilakukan oleh Sathis (2011). Dalam Sathis (2011) menyatakan bahwa frekuensi masalah jaringan merupakan faktor yang signifikan dan dominan mempengaruhi perilaku beralih konsumen dalam menggunakan kartu seluler. Hasil penelitian ini juga tidak sesuai dengan yang dilakukan oleh Keaveney (1995). Penelitian tersebut menyatakan bahwa hingga $21,6 \%$ responden beralih menggunakan service lain dikarenakan inconvinience. 7. Rencana baru, diperoleh nilai signifikansi sebesar 0,746yang lebih besar dari á 0,05 . Hal ini berarti bahwa tidak terdapat pengaruh yang signifikan antara variabel rencana baru dengan perilaku beralih dalam menggunakan kartu seluler. Berarti variabel rencana barubukan merupakan faktor yang mempengaruhi perilaku beralih dalam menggunakan kartu seluler. Hasil penelitian sesuai dengan penelitian sebelumnya yang dilakukan oleh
Sathis (2011) yang juga menyatakan bahwa faktor rencana baru bukan merupakan faktor yang signifikan mempengaruhi konsumen dalam beralih menggunakan kartu seluler lain. 8. Rencana untuk kelompok umur yang berbeda, diperoleh nilai signifikansi sebesar 0,035yang lebih kecil dari á 0,05 dan nilai $\mathrm{R}$ sebesar 0,4102 . Hal ini berarti bahwa terdapat pengaruh yang signifikan antara variabel rencana untuk kelompok umur yang berbeda dengan perilaku beralih dalam menggunakan kartu seluler. Berarti variabel rencana untuk kelompok umur yang berbedamerupakan faktor yang dapat mempengaruhi perilaku beralih dalam menggunakan kartu seluler secara signifikan.

Hasil penelitian ini tidak sesuai dengan penelitian sebelumnya yang dilakukan oleh Sathis (2011), yang menyatakan bahwa rencana untuk kelompok umur yang berbeda bukan merupakan faktor yang signifikan dan dominan mempengaruhi perilaku beralih konsumen dalam menggunakan kartu seluler. 9. Biaya layanan tambahan, diperoleh nilai signifikansi sebesar 0,668 yang lebih besar dari $\alpha 0,05$. Hal ini berarti bahwa tidak terdapat pengaruh yang signifikan antara variabel biaya layanan tambahan dengan perilaku beralih dalam menggunakan kartu seluler. berarti variabel Biaya layanan tambahan bukan merupakan faktor yang mempengaruhi perilaku beralih dalam menggunakan kartu seluler. Hasil penelitian sesuai dengan penelitian sebelumnya yang dilakukan oleh Sathis (2011) yang juga menyatakan bahwa faktor biaya layanan tambahanbukan merupakan faktor yang signifikan mempengaruhi konsumen dalam beralih menggunakan kartu seluler lain. Hasil penelitian ini tidak sesuai dengan yang dilakukan oleh Keaveney (1995).

Dalam penelitian Keaveney (1995) biaya layanan tambahan termasuk dalam sub kategori variabel pricing. Variabel pricing merupakan variabel yang berpengaruh terbesar ketiga dalam service switching. Sebesar 30\% responden menyebutkan bahwa pricing sebagai faktor yang menyebabkan service switching. Dalam penelitian tersebut terdapat $21 \%$ responden yang beralih menggunakan service lain dikarenakan variabel pricingsebagai alasannya. 10. Tarif panggilan, 
diperoleh nilai signifikansi sebesar 0,029 yang lebih kecil dari $\alpha 0,05$ dan nilai $\mathrm{R}$ sebesar 0,4019 . Hal ini berarti bahwa terdapat pengaruh yang signifikan antara variabel tarif panggilandengan perilaku beralih dalam menggunakan kartu seluler. Berarti variabel Tarif panggilanmerupakan faktor yang dapat mempengaruhi perilaku beralih dalam menggunakan kartu seluler secara signifikan. Hasil penelitian sesuai dengan penelitian sebelumnya yang dilakukan oleh Sathis (2011) yang juga menyatakan bahwa faktor tarif panggilan merupakan faktor yang signifikan dan dominan mempengaruhi konsumen dalam beralih menggunakan kartu seluler lain. Hasil penelitian juga sesuai dengan yang dilakukan oleh Keaveney (1995). Dalam penelitian Keaveney (1995) tarif panggilan termasuk dalam sub kategori variabel pricing. Variabel pricing merupakan variabel yang berpengaruh terbesar ketiga dalam service switching. Sebesar 30\% responden menyebutkan bahwa pricing sebagai faktor yang menyebabkan service switching. Dalam penelitian tersebut terdapat $21 \%$ responden yang beralih menggunakan service lain dikarenakan variabel pricing sebagai alasannya. Tarif yang disembunyikan, diperoleh nilai signifikansi sebesar 0,523 yang lebih besar dari $\alpha 0,05$. Hal ini berarti bahwa tidak terdapat pengaruh yang signifikan antara variabel Tarif yang disembunyikandengan perilaku beralih dalam menggunakan kartu seluler. berarti variabel tarif yang disembunyikan bukan merupakan faktor yang mempengaruhi perilaku beralih dalam menggunakan kartu seluler. Hasil penelitian sesuai dengan penelitian sebelumnya yang dilakukan oleh Sathis (2011) yang juga menyatakan bahwa faktor tarif yang disembunyikan bukan merupakan faktor yang signifikan mempengaruhi konsumen dalam beralih menggunakan kartu seluler lain.

Hasil penelitian ini tidak sesuai dengan yang dilakukan oleh Keaveney (1995). Dalam penelitian Keaveney (1995) tarif yang disembunyikan termasuk dalam sub kategori variabel pricing. Variabel pricing merupakan variabel yang berpengaruh terbesar ketiga dalam service switching. Sebesar $30 \%$ responden menyebutkan bahwa pricing sebagai faktor yang menyebabkan service switching. Dalam penelitian tersebut terdapat $21 \%$ res- ponden yang beralih menggunakan service lain dikarenakan variabel pricingsebagai alasannya. 12. Tarif SMS, diperoleh nilai signifikansi sebesar 0,057yang lebih besar dari á 0,05 .Hal ini berarti bahwa tidak terdapat pengaruh yang signifikan antara variabel tarif SMS dengan perilaku beralih dalam menggunakan kartu seluler. berarti variabel Tarif SMS bukan merupakan faktor yang mempengaruhi perilaku beralih dalam menggunakan kartu seluler.

Hasil penelitian sesuai dengan penelitian sebelumnya yang dilakukan oleh Sathis (2011)yang juga menyatakan bahwa faktor tarif SMS bukan merupakan faktor yang signifikan mempengaruhi konsumen dalam beralih menggunakan kartu seluler lain. Hasil penelitian ini tidak sesuai dengan yang dilakukan oleh Keaveney (1995). Dalam penelitian Keaveney (1995) tarif SMS termasuk dalam sub kategori variabel pricing. Variabel pricing merupakan variabel yang berpengaruh terbesar ketiga dalam service switching. Sebesar $30 \%$ responden menyebutkan bahwa pricing sebagai faktor yang menyebabkan service switching. Dalam penelitian tersebut terdapat $21 \%$ responden yang beralih menggunakan service lain dikarenakan variabel pricingsebagai alasannya. 13. Tarif internet, diperoleh nilai signifikansi sebesar 0,023yang lebih kecil dari á 0,05 . Hal ini berarti bahwa terdapat pengaruh yang signifikan antara variabel tarif internet dengan perilaku beralih dalam menggunakan kartu seluler. Berarti variabel tarif internet merupakan faktor yang dapat mempengaruhi perilaku beralih dalam menggunakan kartu seluler secara signifikan.

Hasil penelitian tidak sesuai dengan penelitian sebelumnya yang dilakukan oleh Sathis (2011) yang menyatakan bahwa faktor tarif internet bukan merupakan faktor yang signifikan mempengaruhi konsumen dalam beralih menggunakan kartu seluler lain. Hasil penelitian sesuai dengan yang dilakukan oleh Keaveney (1995). Dalam penelitian Keaveney (1995) tarif internet termasuk dalam sub kategori variabel pricing. Variabel pricing merupakan variabel yang berpengaruh terbesar ketiga dalam service switching. Sebesar 30\% responden menye- 
butkan bahwa pricing sebagai faktor yang menyebabkan service switching. 14. Fasilitas isi ulang, diperoleh nilai signifikansi sebesar 0,222 yang lebih besar dari $\alpha 0,05$. Hal ini berarti bahwa tidak terdapat pengaruh yang signifikan antara variabel fasilitas isi ulang dengan perilaku beralih dalam menggunakan kartu seluler. Berarti variabel fasilitas isi ulang bukan merupakan faktor yang mempengaruhi perilaku beralih dalam menggunakan kartu seluler.

Hasil penelitian sesuai dengan penelitian sebelumnya yang dilakukan oleh Sathis (2011) yang juga menyatakan bahwa faktor fasilitas pengisian pulsa bukan merupakan faktor yang signifikan mempengaruhi konsumen dalam beralih menggunakan kartu seluler lain. Hasil penelitian ini juga tidak sesuai dengan yang dilakukan oleh Keaveney (1995). Dalam penelitian Keaveney (1995) fasilitas pengisian pulsa termasuk dalam sub kategori variabel inconvinience. Penelitian tersebut menyatakan bahwa hingga $21,6 \%$ responden beralih menggunakan service lain dikarenakan inconvinience. 15. Tawaran dari pesaing, diperoleh nilai signifikansi sebesar 0,219 yang lebih besar dari á 0,05 . Hal ini berarti bahwa tidak terdapat pengaruh yang signifikan antara variabel tawaran dari pesaing dengan perilaku beralih dalam menggunakan kartu seluler. Berarti variabel tawaran dari pesaing bukan merupakan faktor yang mempengaruhi perilaku beralih dalam menggunakan kartu seluler. Hasil penelitian sesuai dengan penelitian sebelumnya yang dilakukan oleh Sathis (2011) yang juga menyatakan bahwa faktor tawaran dari pesaing bukan merupakan faktor yang signifikan mempengaruhi konsumen dalam beralih menggunakan kartu seluler lain. Hasil penelitian ini tidak sesuai dengan yang dilakukan oleh Keaveney (1995). Dalam penelitian Keaveney (1995) tawaran dari pesaing termasuk dalam sub kategori variabel attraction by competitor. Penelitian tersebut menyatakan bahwa sekitar $10 \%$ responden beralih menggunakan service lain dikarenakan adanya faktor attraction by competitor. Kemudian Pengaruh keluarga dan teman, diperoleh nilai signifikansi sebesar 0,763 yang lebih besar dari á 0,05 . Hal ini berarti bahwa tidak terdapat pengaruh yang signifikan antara variabel pengaruh keluarga dan teman dengan perilaku beralih dalam menggunakan kartu seluler. Berarti variabel pengaruh keluarga dan teman bukan merupakan faktor yang mempengaruhi perilaku beralih dalam menggunakan kartu seluler.

Hasil penelitian tidak sesuai dengan penelitian sebelumnya yang dilakukan oleh Sathis (2011). Dalam penelitian Sathis (2011) menyatakan bahwa faktor pengaruh keluarga dan teman merupakan faktor yang signifikan dan dominan mempengaruhi konsumen dalam beralih menggunakan kartu seluler lain. 16. Nomor cantik, diperoleh nilai signifikansi sebesar 0,004yang lebih kecil dari á 0,05. Hal ini berarti bahwa terdapat pengaruh yang signifikan antara variabel nomor cantik dengan perilaku beralih dalam menggunakan kartu seluler. Berarti variabel nomor cantik merupakan faktor yang dapat mempengaruhi perilaku beralih dalam menggunakan kartu seluler secara signifikan dan paling dominan. Hasil penelitian tidak sesuai dengan penelitian sebelumnya yang dilakukan oleh Sathis (2011). Dalam penelitian Sathis (2011) menyatakan bahwa faktor nomor cantik bukan merupakan faktor yang signifikan mempengaruhi konsumen dalam beralih menggunakan kartu seluler lain. Biaya isi ulang, diperoleh nilai signifikansi sebesar 0,732 yang lebih besar dari $\alpha 0,05$. Hal ini berarti bahwa tidak terdapat pengaruh yang signifikan antara variabel biaya isi ulang dengan perilaku beralih dalam menggunakan kartu seluler. Berarti variabel biaya isi ulang bukan merupakan faktor yang mempengaruhi perilaku beralih dalam menggunakan kartu seluler.

Hasil penelitian sesuai dengan penelitian sebelumnya yang dilakukan oleh Sathis (2011)yang juga menyatakan bahwa biaya isi ulang bukan merupakan faktor yang signifikan mempengaruhi konsumen dalam beralih menggunakan kartu seluler lain. Hasil penelitian sesuai dengan yang dilakukan oleh Keaveney (1995). Dalam penelitian Keaveney (1995) biaya isi ulang termasuk dalam sub kategori variabel pricing. Variabel pricing merupakan variabel yang berpengaruh terbesar ketiga dalam service switching. Sebesar 30\% responden menyebutkan bahwa pricing sebagai faktor yang menyebabkan service switching. Dalam penelitian tersebut terdapat $21 \%$ responden yang beralih meng- 
gunakan service lain dikarenakan variabel pricing sebagai alasannya.

\section{SIMPULAN}

Berdasarkan hasil penelitian, dapat disimpulkan sebagai berikut; yang pertama faktor-faktor perilaku beralih konsumen secara simultan berpengaruh terhadap perilaku beralih konsumen dalam menggunakan kartu seluler. Variabel yang paling memberikan pengaruh signifikan adalah kesalahan customer service, rencana untuk kelompok umur yang berbeda, tarif panggilan, tarif SMS, tarif internet dan nomor cantik. Kedua Variabel nomor cantikmemberikan pengaruh yang dominan terhadap perilaku beralih dalam menggunakan kartu seluler.

Berdasarkan hasil jawaban responden, kartu seluler yang digunakan sekarang sudah memberikan pelayanan, tarif, dan produk yang sesuai dengan keinginan konsumen, tetapi tidak menutup kemingkinan jika ada tawaran yang lebih menarik dari pesaing maka akan konsumen tersebut akan beralih menggunakan kartu seluler lain. Sebagian besar pengguna kartu seluler sangat rentan untuk berperilaku beralih (switch), karena lebih banyak lebih banyak pengguna kartu seluler yang beralih (switcher) daripada yang tidak beralih (stayer). Adapun saran dari penelitian bagi peneliti selanjutnya yakni hasil penelitian ini dapat dijadikan referensi bagi penelitian selanjutnya dengan topik yang sama agar menambah variabel-variabel baru, cakupan responden yang lebih spesifik, penelitian hanya untuk beberapa provider tertentu supaya hasil penelitian tidak bias dan menggunakan alat analisis yang berbeda supaya mendapatkan hasil yang lain sehingga dapat ditemukan hasil penelitian yang berbeda, dan selalu baru, kemudian bagi provider atau operator kartu seluler, berdasarkan hasil penelitian yang menghasilkan kesimpulan di atas, maka provider hendaknya semakin berinovasi dalam memberikan pelayanan kepada konsumen. Menjaga agar selalu bisa memberikan tarif panggilan, tarif SMS, dan tarif internet tetap bersaing bahkan menjadi yang paling mudah. Penyedia jasa seluler juga memberikan program-program yang sesuai dengan kebutuhan konsumen berdasarkan usia agar program bisa dimanfaatkan secara maksimal oleh konsumen.

\section{DAFTAR PUSTAKA}

Aaker, David A. 1996. Building Strong Brands. Penerbit Division of Simon \& Schuster Inc. New York

Engel, F james. 1996. Perilaku Konsumen, Jilid 1, Penerbit Binarupa Aksar

Keaveney, Susan M. 1995. Customer Switching Behaviour in Service Industries: An Explanatoty Study. Journal Of Marketing. Vol 59 No 2

Keaveney, Susan M. Parthasarathy, Madhavan. 2001, Customer Switching Behavior in Online Services: An Exploratory Study of the Role of Selected Attitudinal, Behavioral, and Demographic Factors. Journal of the Academy of Marketing Science. Volume 29, No. 4, pages 374-390.

Kotler, Philip. 2002, Manajemen Pemasaran di Indonesia: Analisis, Perencanaan, implementasi, dan Pengendalian. Salemba Empat, Jakarta.

Lee, Richard. Murphy, Jamie. From Loyalty To Switching: Exploring The Determinants In The Transition. University of Western Australia

Maholtra 1993, Aplied Multivariate Analisysis, First Edition, Penerbit PT.Gramedia Pustaka, Jakarta.

Samuel. 2001, Analisis Faktor-Faktor Yang Mempengaruhi Terbentuknya Service Switching Pada Pelanggan Telepone Fix Line Di PT Telkom Dirve -IV Jateng DIY. Tesis

Sathis, M. 2011, A Study on Consumer Switching Behaviour in Cellular Service Provider: A Study with reference to Chennai. Far East Journal of Psychology and Business. Vol 2 No 2

Simamora, Bilson. 2004. Panduan Riset Perilaku Konsumen. Penerbit PT Gramedia Pustaka Utama. Jakarta 
Sudjana. 1992, Metode Statistik Edisi V. Penerbit Tarsito Bandung.

Sugiyono. 2002. Metode Penelitian Administrasi. Cetakan Kedelapan. Alfabeta. bandung

Widayat. 2004, Metode Penelitian Pemasaran Aplikasi Software SPSS. Penerbit UMM Press. Malang
Xavier, Patrick. 2008, Enhancing Competition In Telecomunication: Protecting And Empowering Consumers. Faculty of Business, Swinburne University of Technology. Korea

Zikiene, Kristina. 2011, Research Of Influencing Loyal Customer Switching Behaviour. Internet 